\title{
LIMITES DO PODER DE POLÍCIA DA ADMINISTRAÇÃO PÚBLICA
}

\section{Felipe Barbosa de Menezes}

Mestrando em Direito Processual pela Universidade Federal do Espírito Santo - UFES. Pós Graduado em Direito Público com Ênfase em Magistério Superior pela UNISUL/SC. Graduado em Direito pela Faculdade de Direito de Vitória - FDV. Vice-Presidente da Comissão de Advogados Públicos da OAB - ES. Procurador do Município de Cariacica-ES. Advogado e Consultor Jurídico.

Endereço: Alameda Mary Ubirajara, nº 110, apto 602, Santa Lúcia, Vitória-ES, CEP 29056-030.

Contato: (27) 98119.3666; (27) 3039.8006; felipe@menezespinasco.com.br

\section{Pedro Gallo Vieira}

Mestre em Direitos Fundamentais pela Faculdade de Direito de Vitória - FDV. Secretário-Geral da Comissão de Advogados Públicos da OAB - ES. Advogado da União.

Endereço profissional: Procuradoria da União. Rua Professor Almeida Cousin, 125 - $18^{\circ}$ andar, Enseada do Suá, 29050565, - Vitoria, ES - Brasil Telefone: (27) 30414206; 


\section{LIMITES DO PODER DE POLÍCIA DA ADMINISTRAÇÃO PÚBLICA}

\section{LIMITS OF GOVERNMENT'S POLICE POWER}

Resumo: O presente trabalho tem a finalidade de realizar uma análise dos limites do poder de polícia exercido pela Administração Pública em face do particular, no momento em que restringe direitos e liberdades individuais em prol do interesse público. Com o presente estudo, restarão esclarecidas as principais formas de limitação da polícia administrativa, notadamente no que tange aos direitos fundamentais dos indivíduos, aos elementos ou pressupostos do ato administrativo e aos princípios constitucionais da legalidade, razoabilidade e proporcionalidade.

Palavras-Chave: Poder de polícia; limites; interesse público; direitos; princípios.

Abstract: This study aims to conduct an analysis of the limits of police power exercised by the public authorities in particular face, when restricting individual rights and freedoms in the public interest. With this study, there will remain enlightened forms of limitation of administrative police, especially with regard to the fundamental rights of individuals, the elements or assumptions of the administrative act and the constitutional principles of legality, reasonableness and proportionality.

Keywords: Police power; limits; public interest; rights; principles.

\section{Introdução}

É fundamental para a vida em sociedade a valorização do chamado interesse público, 
devendo o Estado, para garantir a manutenção da ordem e propiciar condições ideais para que a própria sociedade possa atingir seus fins sociais, econômicos e culturais, utilizar dos mecanismos necessários para atender a esse interesse geral.

Desse modo, o Poder Público deve fazer prevalecer o interesse geral em relação ao interesse particular, mesmo que para isso tenha que restringir e limitar o uso e gozo de bens, serviços, atividades e direitos e liberdades individuais, ou até mesmo aplicar sanções em caso de desobediência. Tudo se dá em benefício da coletividade.

Essa faculdade da Administração Pública de utilizar-se de atos coercitivos necessários para sobrepor esse interesse público ao privado, contendo assim, muitas vezes, abusos do direito individual (que inclusive se revela nocivo ou inconveniente ao bem estar social, ao desenvolvimento e a segurança da sociedade) chama-se Poder de Polícia, que espelha a eterna tensão entre a autoridade e a liberdade.

Com efeito, observa-se a grande relevância do Poder de Polícia exercido pela Administração Pública, a partir do momento que esta utiliza tais medidas para assegurar a moral, a saúde, a segurança e a ordem pública, dentre outros valores.

Mas, e quando há abuso no exercício deste Poder Administrativo, por parte do agente público competente, tornando-o excessivo e desnecessário? Ou quando, por exemplo, existe arbitrariedade num fechamento de um estabelecimento ou demolição de uma construção? Ou até mesmo autoritarismo exagerado do agente ao abordar um cidadão e submetê-lo ao teste do bafômetro ou qualquer outra medida de polícia?

Assim, cabe-nos então indagar: Quais seriam os limites, e seus fundamentos, do poder de polícia exercido pela Administração Pública em relação ao particular? Até onde o agente público encarregado pode utilizar-se de tais atos coercitivos sem extrapolar no exercício de sua função 
conferida pela Administração?

\section{A Atividade de Polícia: Conceito, Características e Espécies}

É oportuna, antes de adentrarmos no estudo dos limites do Poder de Polícia, a análise da conceituação, das características e dos tipos de espécies de tal atividade estatal, diariamente exercida pelo Poder Público, nos mais diversos campos.

A Carta Constitucional de 1988 assegurou inúmeros direitos e garantias ao cidadão brasileiro. Torna-se importante, todavia, compatibilizar tais conquistas com o bem-estar social. Sendo assim, o mecanismo existente para assegurar que o exercício das liberdades individuais não fira o interesse da sociedade como um todo é chamado de poder de polícia.

Abrahão José Kfouri Filho (1998, p. 101) conceitua o poder de polícia como sendo a “faculdade de que dispõe a Administração Pública para condicionar e restringir o uso e gozo de bens, atividades e direitos individuais em benefício da coletividade ou do próprio Estado”.

Segundo Maria Sylvia Zanella Di Pietro (2007, p. 104), que também chama tal poder estatal de "limitações administrativas", conceitua-o como a "atividade do Estado consistente em limitar o exercício dos direitos individuais em benefício do interesse público".

Interessante, ainda, é a definição apresentada por Hely Lopes Meirelles (2004, p. 129) que, em linguagem menos técnica, conceitua poder de polícia como

\footnotetext{
o mecanismo de frenagem de que dispõe a Administração Pública para conter os abusos do direito individual. Por esse mecanismo, que faz parte de toda Administração, o Estado detém a atividade dos particulares que se revelar contrária, nociva ou inconveniente ao bem-estar social, ao desenvolvimento e à segurança nacional.
}

O próprio Código Tributário Nacional, em seu art. 78, traz um amplo conceito de poder de polícia do Estado, tendo em vista ser o exercício deste um dos fatos geradores das taxas. É, 
inclusive, a nosso ver, uma das definições mais completas encontradas ao longo do estudo. Oportuna, pois, a transcrição do referido dispositivo legal:

Art. 78. Considera-se poder de polícia atividade da administração pública que, limitando ou disciplinando direito, interesse ou liberdade, regula a prática de ato ou abstenção de fato, em razão de interesse público concernente à segurança, à higiene, à ordem, aos costumes, à disciplina da produção e do mercado, ao exercício de atividades econômicas dependentes concessão ou autorização do Poder Público, à tranquilidade pública ou ao respeito à propriedade e aos direitos individuais ou coletivos.

Por outro lado, Celso Antônio Bandeira de Mello (2006, p. 780) avança na conceituação de poder de polícia, abordando tal atividade estatal em seu sentido amplo e restrito, levando-se em conta as atividades legislativa e executiva de polícia. No primeiro caso, entende-se como poder de polícia todos os atos de polícia compreendidos no âmbito do Poder Legislativo, ou seja, as normas legislativas limitadoras, e do Poder Executivo. ${ }^{1}$

No entanto, o conceito strictu sensu, aponta o professor, abrange somente atos do Executivo, relacionando-se somente com as intervenções, sejam elas gerais e abstratas, como os chamados regulamentos, ou concretas e específicas, como as autorizações e licenças do Poder Executivo, "destinadas a alcançar o mesmo fim de prevenir e obstar o desenvolvimento de atividades particulares contrastantes com os interesses sociais" (MELLO, 2006, p. 780).

É ele, na realidade, o poder de polícia propriamente dito, que designa uma função tipicamente administrativa do Poder Público.

Como se pode observar, diversos são os conceitos atribuídos ao poder de polícia pela doutrina nacional, estrangeira e pela legislação específica, porém sem grandes divergências, 
chegando todos à conclusão, em linhas gerais, de ser tal atividade aquela que visa, de inúmeras formas, à limitação de liberdades individuais em prol do interesse público.

O poder de polícia administrativa, ao ser considerado como um dever estatal que busca a prevenção de um dano à coletividade, em decorrência de eventual conduta abusiva ou inconveniente ao Estado, através de instrumentos de fiscalização e controle das ações dos particulares, é visto como uma atividade de caráter negativo.

Isso porque, na grande maioria das vezes, impõe uma abstenção ao cidadão, uma obrigação de não fazer. Ao impor condições e limitações, o Estado restringe a atuação dos administrados para resguardar o interesse público. É, portanto, em linhas gerais, um poder negativo que se distingue, sob tal aspecto, do serviço público, atividade tipicamente positiva (DI PIETRO, 2007, p. 108).

Embora em quase todos os casos tenha um sentido, de fato, negativo, certo é que o poder de polícia não se demonstra sempre assim, dependendo muito do ângulo de análise do caso concreto. Tanto faz dizer que através dele se evita um dano, quanto que por seu intermédio se constrói uma utilidade para a coletividade (MELLO, 2006, p. 788)².

Existem, basicamente, três importantes características da atividade administrativa de polícia: a discricionariedade, a auto-executoriedade e a coercibilidade. É claro que, antes de qualquer interpretação, tais aspectos devem ser sempre analisados sob a ótica do princípio da legalidade, a fim de evitar abusos por parte do Estado.

No que tange à característica de discricionariedade, o poder de polícia terá caráter discricionário quando a lei possibilitar ao Poder Público fazer um juízo de conveniência e oportunidade da forma de agir. Assim, deixando a lei uma "brecha", a Administração poderá decidir 
qual o melhor momento e meio mais adequado para atuar, assim como qual a sanção cabível dentre as que a norma prevê (DI PIETRO, 2007, p. 106).

A restrição policial será discricionária quando, por exemplo, determinada autoridade impõe proibição de pesca somente em alguns rios (ela pode escolher) ou no caso de concessão de autorização para porte de arma de fogo, para circulação de veículos com determinado peso ou altura ou para a produção de material bélico. Nota-se que aqui ela tem liberdade para, em cada caso, analisar e decidir se deve concedê-la, levando em conta o interesse geral. Estes casos, e inúmeros outros, se justificam pelo fato de ser impossível o legislador prever todas as formas e situações de limitações administrativas.

Por óbvio, entretanto, não pode a Administração incorrer em abuso do poder de polícia discricionário, quer por arbitrariedade que por desvio de finalidade, sob pena de ser o ato considerado inválido. Nesta linha, Hely Lopes Meirelles (2004, p. 134) diz que a discricionariedade “é liberdade de agir dentro dos limites legais; arbitrariedade é ação fora ou excedente da lei, com abuso ou desvio de poder. $\mathrm{O}$ ato discricionário, quando se atém aos critérios legais, é legítimo e válido; o ato arbitrário é sempre ilegítimo e inválido".

No que tange à auto-executoriedade, esta é a característica que permite ao Estado pôr em prática seus atos de polícia sem a prévia autorização do Poder Judiciário, como os atos administrativos de modo geral ${ }^{3}$.

O sentido de tal característica é demonstrado por José dos Santos Carvalho Filho (2007, p. 79):

A prerrogativa de praticar atos e colocá-los em imediata execução, sem dependência à manifestação judicial, é que representa a auto-executoriedade. Tanto é auto-executória a restrição imposta em caráter geral, como a que se dirige diretamente ao indivíduo, quando, 
por exemplo, comete transgressões administrativas. É o caso da apreensão de bens, interdição de estabelecimentos e destruição de alimentos nocivos ao consumo público.

Verificada a presença dos pressupostos legais do ato, a Administração pratica-o imediatamente e o executa de forma integral. Esse é o sentido da auto-executoriedade. (grifo do autor)

Segundo a doutrina de Maria Sylvia Zanella Di Pietro (2007, p. 107), a referida característica se desdobra nos princípios da exigibilidade e da executoriedade. Quanto ao primeiro princípio, o Estado tem a possibilidade de tomar decisões executórias sem manifestação decisória alguma do Poder Judiciário, ainda que sem a concordância do administrado. Em relação ao segundo princípio, este dá à Administração a prerrogativa de se valer de atos diretos de execução forçada, utilizando inclusive, caso seja necessário, a força pública para forçar o cumprimento da decisão. ${ }^{3}$

No entanto, a característica em questão não é absoluta. Ela não existe em todas as possíveis medidas de poder de polícia. Autores como Celso Ribeiro Bastos (1996, p. 154) entendem que as limitações administrativas, se necessárias, devem ser impostas somente em situações que sejam, de fato, indispensáveis, como quando a lei expressamente autorizar, quando a adoção da medida requer urgência e não comportar a demora normal de um pronunciamento Judiciário ou quando não houver outra via de direito capaz de assegurar a satisfação do interesse público, cuja defesa compete à administração pública.

Isto posto, é de se observar que a auto-execução de atos de polícia por parte da Administração é essencial para a própria efetividade do poder limitador estatal, mas somente se não incorrer em arbitrariedades ou abusos do agente público, a fim de não lesar a legalidade, a proporcionalidade e a razoabilidade, princípios limitadores a serem posteriormente tratados por este trabalho. 
Outro relevante atributo a ser considerado é o da coercibilidade do poder de polícia do Estado, o qual se caracteriza pela imposição coativa das medidas limitadoras, pela Administração Pública, ao particular, obrigando-o a lhes prestar obediência.

Segundo José dos Santos Carvalho Filho (2007, p. 80), esta característica ilustra o grau de imperatividade de que se revestem os atos provenientes da atividade de polícia, a qual corresponde a um poder (ius imperii estatal), que naturalmente deve ser desempenhado de forma a obrigar todos a observarem os seus comandos.

Desta forma, é essencial a existência de um mecanismo que faça, de fato, valer o poder de polícia, de modo a efetivar o cumprimento das limitações estatais em prol do interesse coletivo. Assim, deve haver algo que obrigue os administrados. É ai que se constitui a coercibilidade.

É importante observar, ainda, que é impossível dissociar a coercibilidade da autoexecutoriedade, vez que um ato administrativo de polícia somente pode ser auto-executável se possuir força coercitiva perante a figura do particular (DI PIETRO, 2007, p. 108).

Assim, em situações em que tais limitações impostas não sejam obedecidas pelo administrado, a lei permite, inclusive, o emprego da força física como meio de coagir o infrator ao cumprimento da imposição estatal. Por óbvio, uso da força deve ser proporcional e razoável para o restabelecimento da ordem, até mesmo porque a Constituição Federal não admite a violência. Caso haja excesso por parte da autoridade ou agente competente, é certo que incorrerão em abuso de poder, podendo responder pelas sanções legais cabíveis nas esferas cíveis, administrativas e penais. ${ }^{4}$

Por fim, importante registrar que o poder de polícia exercido pelo Estado também se divide em duas espécies: polícia Administrativa e polícia Judiciária. A grande maioria da doutrina nacional 
faz referência à distinção destas modalidades, razão pela qual cabe uma análise, ainda que breve, em relação a tais espécies de atividade de polícia.

Primeiramente, cabe ressaltar que tal distinção de polícia se dá em razão de cada uma delas ter objetivos diferentes, buscarem fins distintos. Assim, a princípio, entende-se que a polícia Administrativa possui caráter preventivo, enquanto a Judiciária age repressivamente.

Entretanto, não se pode ver o critério “prevenção/repressão" como absoluto. Isto porque, em inúmeras situações, a atividade de polícia administrativa será, de fato, exercida de forma repressiva, como veremos posteriormente.

Com efeito, segundo o ensinamento de Odete Medauar (2005, p. 380):

\footnotetext{
Em essência, a polícia administrativa ou poder de polícia, restringe o exercício das atividades lícitas, reconhecidas pelo ordenamento como direitos dos particulares, isolados ou em grupo. Diversamente, a polícia judiciária visa a impedir o exercício das atividades ilícitas, vedadas pelo ordenamento; a polícia judiciária auxilia o Estado e o Poder Judiciário na prevenção e repressão de delitos; e auxilia o Judiciário no cumprimento de suas sentenças (v. CF, art. 144, incisos e parágrafos).
}

Maria Sylvia Zanella Di Pietro (2007, p. 105) diferencia as modalidades de polícia, com base em sua incidência, de modo que a polícia administrativa se rege pelo ramo do Direito Administrativo, incidindo sobre direitos, atividades e bens, ao passo que a judiciária rege-se pelo direito processual penal, a incidir sobre pessoas.

Brilhantemente, Celso Antônio Bandeira de Mello (2006, p. 793) traça a diferença "chave" entre as duas polícias estatais: “o que efetivamente aparta polícia administrativa de polícia judiciária é que a primeira se predispõe unicamente a impedir ou paralisar atividades anti-sociais enquanto a segunda se preordena à responsabilização dos violadores da ordem jurídica”. (grifo do autor) 
Com efeito, a polícia administrativa "é inerente e se difunde por toda administração Pública", ao passo que o restante das atividades de polícia ficam a cargo de órgãos e de corporações, como as Polícias Civis (MEIRELLES, 2004, p. 129).

Assim, ela atua através de agentes devidamente credenciados por órgãos públicos a fim de evitar a ocorrência de atos que lesem normas de Direito Administrativo, impedindo a conduta considerada antissocial. Por outro lado, a atividade de polícia judiciária busca, por meio de seus agentes (policiais civis), a repressão ao crime (FARIA, 2004, p. 162).

A polícia administrativa, por ser o poder de polícia propriamente dito, é que nos interessa para no desenvolvimento do presente estudo. Posto desta maneira, torna-se importante, agora, a verificação dos atos através dos quais a mesma se expressa.

Segundo Bandeira de Mello (2006, p. 793), a atividade de polícia administrativa pode-se manifestar por meios de atos normativos de caráter geral e através de atos concretos e específicos. Assim ocorre quando há regulamentos que proíbem soltar balões em época de festa junina ou normas administrativas que disciplinem condições para a venda de bebidas alcoólicas em determinados locais (atos normativos de alcance geral) ou quando há dissolução de reunião subversiva, censura de propaganda imoral ou guinchamento de carro que esteja obstruindo via pública (estes concretos e específicos). São estes os atos materiais de polícia, através de condutas repressivas.

Há também, a expressão de tal forma de poder através de atos administrativos de polícia, também concretos e específicos, mas de caráter preventivo. Neste caso, o Poder Público atua realizando medidas preventivas relativas à concessão de autorizações ou licenças, à emissão de ordens ou notificações ou à realização de fiscalizações e vistorias em determinados estabelecimentos privados, no que tange à obediência das normas de segurança, de higiene e de salubridade (DI PIETRO, 2007, p. 106). 
Enfim, como se pode observar, nem sempre a atividade de polícia administrativa vai ser exercida em caráter preventivo. Conforme alguns casos citados, o Poder Público vai valer-se de determinados atos tipicamente de polícia administrativa, mas que só podem se concretizar de forma repressiva contra o particular, para fazer prevalecer o interesse público e cessar os comportamentos e condutas antissociais.

\section{Limites do poder de polícia}

Neste momento, adentraremos diretamente no estudo do tema escolhido, analisando as principais formas de limitação da atividade de polícia administrativa.

Com efeito, tal faculdade estatal de restrição de direitos e liberdades individuais, em prol do interesse público e do bem-estar social, deve ser exercida com todos os cuidados que a legislação constitucional e infraconstitucional prevê, a fim de evitar abusos do Poder Público e abolição total de garantias do cidadão. Está sujeito o Estado, portanto, a certos limites no exercício do poder de polícia.

É de se observar que na atualidade jurídica entre os debates neoconstitucionais, o grande embate está em lapidarmos uma forma democrática de aferirmos o que venha a ser esse interesse este interesse coletivo capaz de se sobrepor à individualidade. O Estado, apesar de ontologicamente expressar-se juridicamente como uma pessoa jurídica, é formado por toda sociedade e deve perseguir os valores que esta sociedade venha a apontar (BARROSO in SARMENTO, 2007, p. x). A titularidade da soberania democrática não se confunde com o seu exercício. Embora as Constituições se utilizem do povo com vistas a legitimar seu poder, os efetivos titulares do poder ativo tendem a confiar aos governantes o seu exercício. Com efeito, confere-se ao povo o papel de instância global de atribuição de legitimidade, o que justificaria as decisões prolatadas em seu nome (MÜLLER, 1998, p. 60). No entanto, o povo não pode ser entendido apenas e tão somente como fonte legitimadora das normas, seja no processo de produção ou de interpretação, mas também 
como destinatário. Para tanto, compete ao Estado Constitucional observar a atribuição democrática a este imposta, condicionante da permanente legitimação processual de validade do ordenamento jurídico, sobretudo quando do exercício do poder de polícia administrativa.

O que se deve buscar, neste contexto, é um equilíbrio entre o exercício dos direitos individuais de cada cidadão e o interesse coletivo que se busca proteger. Segundo Hely Lopes Meirelles (2004, p. 133), “os limites do poder de polícia administrativa são demarcados pelo interesse social em conciliação com os direitos fundamentais do indivíduo assegurados na Constituição da República (art. $5^{\circ}$ )".

É como trata a questão o professor Diógenes Gasparini (2005, p. 128) que, ao abordar o presente tema, demarca a atividade de polícia estatal por dois limites:

Está a atribuição de polícia demarcada por dois limites: o primeiro se encontra no pleno desempenho da atribuição, isto é, no amplo interesse de impor limitações ao exercício da liberdade e ao uso, gozo e disposição da propriedade. O segundo reside na observância dos direitos assegurados aos administrados pelo ordenamento positivo. É na conciliação da necessidade de limitar ou restringir o desfrute da liberdade individual e da propriedade particular com os direitos fundamentais, reconhecidos a favor dos administrados, que se encontram os limites dessa atribuição (...).

Portanto, como veremos a seguir, certas limitações deverão ser observadas pela Administração Pública no momento de imposição de restrições ao administrado, no que se refere à proporcionalidade e razoabilidade da medida, com a devida observância da competência, da forma, da finalidade, do motivo e do conteúdo do ato de polícia.

\subsection{Limites e os direitos fundamentais}


Como já foi tratado no presente trabalho, o poder de polícia deve ser exercido pelo Estado com certa cautela. Este cuidado se dá pela preocupação em não abolir direitos e liberdades individuais do cidadão em prol da coletividade, mas apenas restringi-los.

Neste diapasão, é certo que os limites da atividade de polícia devem ser demarcados pela conciliação do interesse público, que de fato deve ser protegido, com direitos fundamentais do particular (MEIRELLES, 2004, p. 133). ${ }^{5}$

Certo é que o interesse público visto como mero interesse do Estado nos remete ao absolutismo, quando o este não tinha deveres para com seus cidadãos, mas somente com ele mesmo, representado pelo monarca. Dentro das dimensões dos direitos fundamentais e logo depois das revoluções burguesas que criaram uma fórmula constitucional de contenção do poder, deu-se a mudança de paradigma para o Estado Liberal, passando este a defender os interesses individuais. Remanesce que a função administrativa impõe a observância do interesse público como expressão dos interesses do Povo, do que decorre a sua indisponibilidade, bem como a exigibilidade da prática de atos que melhor atendem à gestão dos interesses de toda a sociedade (VIEIRA e VIEIRA, 2013, p. 200/201).

Com efeito, tais direitos individuais, previstos da Carta Constitucional de 1988 (art. 5º), são, entre outras, garantias que tem o administrado contra atos de outros particulares, que fazem "mau uso" de seus direitos, e até mesmo da própria Administração Pública.

Nelson Schiesari (1982, p. 121) trata da questão de forma clara:

A atuação prática do Estado, quando polícia o comportamento dos indivíduos, tem, todavia, os seus limites, que são os próprios direitos individuais, conferidos pela Constituição ou pela lei. Tais limites constituem verdadeiras barreiras ao arbítrio dos governantes, que podem ser, nos casos de excesso, responsabilizados pelos seus atos danosos. A ação dos 
agentes do Estado a tal propósito é de natureza discricionária, nunca, porém, arbitrária. (grifo do autor)

A professora Odete Medauar (2005, p. 396) também aborda o tema limites da polícia administrativa, apontando os direitos fundamentais como barreiras à intervenção estatal nas liberdades individuais:

O poder de Polícia pode acarretar disciplina e restrições ao exercício de um direito fundamental, em benefício do interesse público. A mesmo tempo, o reconhecimento de direitos fundamentais configura limite ao poder de polícia; os direitos fundamentais não podem ser suprimidos.

Por outro lado, Carlos Ari Sundfeld (2004, p. 33-37) traz uma interessante discussão: poderiam, realmente, os direitos fundamentais se sobreporem ao interesse público? Tal discussão se torna importante em razão de mais uma vez vir à tona a tensão autoridade e liberdade, no que tange ao princípio constitucional da inviolabilidade do domicílio (direito fundamental) e o interesse público (saúde pública).

O mencionado autor, para tratar da questão, analisa o caso do controle de vigilância epidemiológica para prevenção da dengue que depende, na maioria dos casos, da entrada do agente público da vigilância sanitária na casa do particular. Indaga, então, o professor: é viável constitucionalmente o Estado impor às pessoas o dever de suportar o ingresso de agentes sanitários nos ambientes privados? Qual a reação estatal possível em caso de frustração desse ingresso, seja por resistência, seja por ausência do morador?

Desta forma, tem-se o confronto entre o interesse coletivo de prevenção de doenças (saúde pública) e o direito fundamental da inviolabilidade do domicílio, garantido aos indivíduos pela Constituição Federal de 1988. 
Com efeito, Sundfeld demonstra a necessidade de, primeiramente, analisar dois possíveis sentidos para interesse público, a fim de se verificar a viabilidade ou não da mitigação do mencionado direito fundamental. Considera, assim, o "interesse público em sentido mínimo" e o “interesse público em sentido forte":

Quando o direito atribui ao Estado o dever de cuidar de certo valor, está implicitamente definindo-o como interesse público, que legitima a atuação estatal (interesse público em sentido mínimo). Só que isso não importa necessariamente tomada de posição da ordem jurídica quanto à prevalência desse valor sobre os outros, que com ele se choquem, pois algo pode ser sério o bastante para ensejar a atuação do Estado, mas não sê-lo a ponto de justificar o sacrifício de outros bens. Quando o Direito consagra essa prevalência, pode-se falar em interesse público em sentido forte. Essa expressão serve para descrever a relação entre dois valores, um que prevalece (o interesse público em sentido forte) e o que se cede (o interesse simples).

Posto isto, torna-se essencial, então, que se faça uma ponderação de valores e interesses no caso concreto. É preciso avaliar se o interesse por trás do condicionamento merece o "rótulo" de interesse público em sentido forte. Somente assim se resolverá o impasse e se verificará qual interesse é mais relevante a ser protegido no caso real.

Ora, é certo que as ações de polícia administrativa no campo da saúde são, de certa forma, inconvenientes e até onerosas para os particulares, em razão de frequentes intervenções e abstenções a que são obrigados a suportar, como no caso de controle de doenças e vacinações obrigatórias.

No entanto, conforme o entendimento de Sundfeld, ao qual nos filiamos, mesmo se tratando de direito constitucional do indivíduo de ter sua moradia resguardada contra eventual invasão indesejada, tal garantia não se sobrepõe ao interesse coletivo relativo à saúde pública, ao se considerar que este possui caráter de interesse público forte. 
Assim, o interesse público de proteção da saúde coletiva se destaca mais do que o interesse particular, manifestado pelo princípio da inviolabilidade do domicílio, sendo justificável o exercício de atos de polícia sanitária de vigilância epidemiológica no combate à dengue.

É permitido, por consequência, o acesso compulsório de agentes administrativos da área da saúde em ambientes privados, até mesmo sem autorização judicial, utilizando-se, inclusive da força física (se necessária e com moderação, em caso de resistência do morador), já que se trata de medida de caráter geral, sem pessoalidade alguma e sem qualquer apontamento a endereço específico.

Em conclusão, podemos considerar que haverá situações especiais em que o poder público poderá valer de restrições nos direitos e liberdade do indivíduo, mas de forma temporária, devendose analisar, no caso concreto, qual interesse se sobrepõe e qual sacrifício é viável ser realizado, sempre em observância da proporcionalidade e razoabilidade.

\subsection{Limites nos elementos do ato administrativo}

O uso do poder de polícia é considerado, como já tratado, de prerrogativa da autoridade pública. Mas o poder há de ser usado normalmente, sem abuso. Usar "normalmente" tal poder administrativo é empregá-lo segundo as normas legais e a moral da instituição, mas principalmente em conformidade com a finalidade do ato, a forma, o motivo e o objeto, sendo somente exercido pelo agente competente, como os atos administrativos em geral.

Assim, o abuso de poder de polícia se dará a partir do momento que o ato for empregado fora da lei, sem qualquer utilidade pública e sem observar os elementos do ato administrativo.

Com efeito, torna-se essencial a análise dos elementos do ato administrativo, considerados como requisitos de validade para qualquer um dos atos do Poder Público, quais sejam, a 
competência, a finalidade, o motivo, a forma e o conteúdo, conforme dispõe o art. $2^{\circ}$ da Lei $n^{\circ}$. 4717/64, que regula a Ação Popular.

\subsubsection{Competência}

No que tange à competência para a realização do ato administrativo, esta se refere à delimitação das atribuições cometidas ao agente público que pratica o ato, isto é, o sujeito do ato, o qual deve ser capaz civilmente, na forma exigida pelo Código Civil Brasileiro.

Por este requisito, resta claro que o agente capaz encontra o seu correspondente na competência, de modo que, para a validade do ato administrativo, deve ser o mesmo editado por quem detenha competência para tanto (SPITZCOVSKY, 2006, p. 99).

É importante ressaltar, entretanto, que agente competente não é o mesmo que agente capaz, sendo que aquele pressupõe a existência deste. Todavia, capacidade não quer dizer competência, já que, em termos mais simples, não se trata de situação de quem manifeste vontade para realizar o ato, mais sim de quem tem o poder de praticá-lo.

Assim, embora no direito civil o sujeito deva ter capacidade para exercer determinados atos e ser titular de direitos e obrigações da vida cível, no direito administrativo a capacidade não é o bastante. É necessário que o sujeito possua competência (DI PIETRO, 2006, p. 188).

Hely Lopes Meirelles (2004, p. 149) define competência administrativa como

\footnotetext{
“o poder atribuído ao agente da Administração para o desempenho específico de suas funções. A competência resulta da lei e por ela é delimitada. Todo ato emanado de agente incompetente, ou realizado além do limite de que dispõe a autoridade incumbida de sua prática, é inválido, por lhe faltar um elemento básico de sua perfeição, qual seja, o poder jurídico para manifestar a vontade da Administração”.
} 
Desta maneira, no exercício do poder de polícia, o agente público terá competência quando possuir poder legal para praticar o ato de restrição.

A competência para a polícia administrativa, portanto, manifesta-se em diversos setores, como por exemplo, na polícia de caça, competente para a proteção da fauna terrestre; na polícia de tráfego e trânsito, competente para garantir a ordem e a segurança nas rodovias; na polícia sanitária, destinada à defesa da saúde pública, dentre inúmeras outras.

Assim, o chamado desvio de competência ocorrerá caso certo agente, que não tenha o poder legal específico para determinado ato de polícia, o desempenhe, como no caso hipotético de um agente público da polícia de vigilância sanitária emitir multa de trânsito a motorista que trafega irregularmente nas vias ou no caso de agente competente para o exercício do policiamento florestal impedir a realização de espetáculo teatral na cidade, caso de competência exclusiva da polícia de divertimentos públicos.

\subsubsection{Finalidade}

No que se refere à finalidade do ato, a qual sempre será vinculada, devemos considerar que o poder de polícia visará sempre o interesse público. A Administração Pública, nos seus atos de restrição de direitos do administrado, busca sempre atingir o "bem comum", ou seja, a coletividade.

O requisito da finalidade é bem definido pelo professor José dos Santos Carvalho Filho (2007, p. 109):

Finalidade é o elemento pelo qual todo ato administrativo deve estar dirigido ao interesse público. Realmente não se pode conceber que o administrador, como gestor de bens e interesses da coletividade, possa estar voltado a interesses privados. O intuito de sua atividade deve ser o bem comum, o atendimento aos reclamos da comunidade, porque essa de fato é a sua função. (grifo do autor) 
Odete Medauar (2005, p. 159-160) ao tratar do conceito de interesse público, afirma ser este a consequência final de todo ato da Administração Pública, como "a meta a ser atingida mediante o ato administrativo".

É importante ressaltar que alguns autores como Maria Sylvia Zanella Di Pietro (2006, p. 194), defendem existência da finalidade do ato administrativo em dois sentidos distintos: o amplo e o restrito. Na primeira visão, entende-se que o ato administrativo vai ter sempre finalidade pública, ou seja, vai sempre corresponder à "consecução de um resultado de interesse público". Em sentido restrito, a finalidade seria um fim específico que cada ato deve produzir, em observância do que estiver definido na lei.

No entanto, no nosso entendimento, não há fundamento para tal classificação, tendo em visto que sempre, no final, mesmo considerando restritivamente à previsão legal, será o poder de polícia (assim como todos os atos da administração) voltado ao interesse público. A própria lei se preocupará com o interesse geral. Esta é a sua finalidade.

Com efeito, Diógenes Gasparini (2005, p. 63) demonstra que "o ato administrativo desinformado de um fim público e, por certo, informado por um fim de interesse privado é nulo por desvio de finalidade", em razão de passar de uma finalidade de interesse geral para uma de interesse privado.

Enfim, a título de exemplificação, o desvio de finalidade se configurará em situações em que o resultado do ato de polícia seja voltado a interesses particulares, como no caso de ato de desapropriação com fim de prejudicar o proprietário do imóvel ou até própria omissão do agente de trânsito que deixa de aplicar multa ao particular por ser amigo deste.

\subsubsection{Motivo}


Outro requisito de validade do ato administrativo que, sendo observado, limita o exercício da polícia administrativa, é o motivo.

O motivo se configura pela situação cuja ocorrência autoriza ou até determina a prática do ato, sendo ele a justificativa indicada pelo agente público na prática de determinado ato administrativo de sua competência. "A fundamentação consiste em deduzir expressamente a resolução tomada das premissas em que assenta, ou em exprimir os motivos por que se resolve de certa maneira, e não de outra" (CAETANO, 1991, p. 477).

Celso Ribeiro Bastos (1996, p. 95-96) demonstra, também, que obrigação de motivar o ato do Poder Público (incluindo aqui, o poder de polícia, objeto do presente estudo), pode ser de forma vinculada ou até discricionária, dependendo da previsão o ato em questão. No primeiro caso, o agente poderia praticá-lo se houver ocorrida a circunstância prevista e descrita na legislação. No segundo, isto é, quando a lei nada prever, verifica-se uma margem de discricionariedade para o agente público escolher o motivo que justificará a produção do ato.

Com efeito, no caso de exercício do poder de polícia, havendo previsão expressa na legislação, o agente competente deverá motivar conforme exige tal instrumento. Assim, no ato de desapropriação, por exemplo, o órgão da Administração é obrigado a indicar um dos motivos previstos no inciso XXIV do art. $5^{\circ}$ da Carta Constitucional, sob pena de nulidade.

Em contrapartida, na hipótese de não ser determinada a causa para o ato de polícia, na lei, tal conduta será discricionária para o agente. Ocorre que, em se tratando de limitações na propriedade e liberdade individual do particular, a escolha do Poder Público, sem sombra de dúvida, há de ser realizada em observância dos princípios da proporcionalidade e razoabilidade, a fim de evitar arbitrariedades. 
Sendo assim, o motivo, como requisito de validade do ato, deve ser obrigatoriamente observado. Se, de alguma forma, forem inexistentes ou falsos, implicam em sua nulidade. O Estado, ao apresentar certo motivo para o exercício de determinado ato de polícia, mesmo que o texto legal não o exija, está vinculado a ele, só podendo agir com base nele. É o que reza a teoria dos motivos determinantes, em que "os motivos que determinam a vontade do agente, isto é, os fatos que serviram de suporte à sua decisão, integram a validade do ato" (MELLO, 2006, p. 384).

Enfim, a indicação do real motivo para a prática do ato de polícia, com a devida fundamentação, é condição de validade do ato administrativo, devendo obrigatoriamente ser observado pela Administração, mesmo que não haja previsão legal específica para a adoção da medida pertinente, sob pena de nulidade.

\subsubsection{Forma}

No exercício do poder de polícia, a Administração deve sempre atuar, também, em obediência à forma do ato praticado. A forma, como elemento exteriorizador do ato do Poder Público, é também essencial e de extrema relevância, já que é o modo como o tal ato vai se apresentar.

O doutrinador argentino Rafael Bielsa (1938, p. 193) demonstra com clareza a concepção de forma do ato administrativo:

El concepto de forma puede tomarse, desde luego, en diverso sentido y extensión. Así hablamos de forma refiriéndonos a requisitos necesarios para la existencia, validez y eficacia jurídica de los actos. Entendemos también por forma la estructura del acto, es decir, la manera como se manifiesta la declaración de voluntad que necesariamente supone todo acto administrativo. Se habla, finalmente, de forma con referencia a la esfera 
de derecho en que el acto nace o se produce y, en su virtud, a la figura jurídica que él presenta. $^{6}$

Trata-se, portanto, de requisito indispensável à perfeição do ato, justamente por se tratar de vontade do Estado, e não do indivíduo, no âmbito privado (MEIRELLES, 2004, p. 150).

É relevante observar que o motivo do ato é, sem sombra de dúvida, vinculado ao texto legal, ou seja, a atuação do agente público deve ser sempre restrita ao que a legislação prevê, não podendo o mesmo escolher outras formas para o ato, senão as legais. Entretanto, pode haver certa margem de discricionariedade, em hipóteses em que a lei estipule mais de uma maneira de praticar o ato. Há, ainda, vinculação à forma legal, mas a Administração tem possibilidade de escolha da mais conveniente ao interesse público, dentre as que a lei apresenta.

Assim, a importância de se respeitar a forma do ato administrativo está justamente no fato de que através dela que se fiscaliza a validade do ato, o qual será considerado inválido se não for observada a forma apontada pela lei como aquela adequada.

\subsubsection{Objeto}

Por fim, quanto ao objeto ou conteúdo do ato administrativo, é certo que este, como os atos jurídicos em geral, e com muito mais razão, deve obrigatoriamente ser lícito, possível, certo e moral. É ele o efeito imediato produzido ou prescrito pelo ato do agente da Administração Pública.

Segundo a doutrina de Odete Medauar (2005, p. 157), "significa o efeito prático pretendido com a edição do ato administrativo ou a modificação por ele trazida ao ordenamento jurídico”.

Considerando ser o ato administrativo uma espécie de ato jurídico (gênero), sua existência é condicionada à produção de efeito jurídico, isto é, nascimento, extinção ou transformação de 
determinado direito, de modo que tal efeito é justamente o conteúdo do ato (DI PIETRO, 2006, p. 191).

Marcello Caetano, no que tange à produção de tais efeitos, pondera:

$$
\begin{aligned}
& \text { Mas essa produção de efeitos é inseparável do caso concreto que o órgão da Administração } \\
& \text { tem em vista e, de resto, a natureza desses efeitos e sua legalidade dependem dos termos em } \\
& \text { que o caso se apresente e da verificação nele dos pressupostos subjectivos e objectivos, } \\
& \text { situações de facto ou de direito, exigidos por lei, ou invocados como motivos do acto } \\
& \text { (1991, p. 481). }
\end{aligned}
$$

$\mathrm{Na}$ esteira de tais entendimentos, sendo o ato praticado ilegal, imoral, impossível de ocorrer do mundo fático ou jurídico, incerto ou até impossível de ser determinado, será ele nulo e ineficaz.

Com efeito, imaginemos, a título de exemplificação, um ato de polícia com objeto ilícito (contrário ao que a lei determina), o qual produza não só restrições a direitos de determinado administrado, mas até mesmo fira suas garantias individuais ou cause total abolição do direito à liberdade ou à propriedade; ou quando imoral, ou seja, fora dos padrões de comportamento e ética do homem comum, haja com injustiça, gerando sérios danos ao particular. Ora, não deve ser este o efeito do ato produzido pelo poder do polícia da Administração.

Verifica-se aqui, portanto, caso de ato administrativo que não respeitou à legalidade, proporcionalidade e razoabilidade, de grande relevância para que a determinada conduta não seja eivada de nulidade. A obediência à previsão legal, aqui, é essencial.

Por outro lado, e quando o meio de atuação material (objeto) não tem previsão na legislação? Ou quando o mesmo é descrito na lei através de conceitos abertos ou amplos? Imaginemos a forma de atuação de agente da Polícia Militar, no estrito exercício do poder de polícia de manutenção da ordem pública. Ao abordar um cidadão em conduta suspeita, a autoridade se utiliza de procedimento de revista não descrito legalmente. Esta falta de previsão é razoável para 
justamente viabilizar a execução do ato, em razão da impossibilidade do legislador prever todas as possíveis situações de abordagem de delinquentes no caso concreto.

Desta maneira, assim como em casos específicos em que a lei prevê o objeto do ato administrativo, deve o agente público praticá-lo em observância à razoabilidade e proporcionalidade, mesmo quando inexista previsão em lei. Com efeito, não será ilícito o ato, tendo em vista que será gerado efeito prático razoável e proporcional.

Posto isto, torna-se de extrema importância a análise dos princípios da proporcionalidade, da razoabilidade e da legalidade dos atos de polícia administrativa, visto que indispensáveis para a validação do objeto do ato de polícia administrativa.

\subsection{Razoabilidade, proporcionalidade e legalidade}

O limite da polícia administrativa se expressa, também, através dos princípios da razoabilidade, da proporcionalidade e da legalidade.

Desta maneira, no exercício das limitações administrativas pelo agente público competente, este deve, a todo o momento, se valer dos atos necessários para restringir o direito ou a liberdade do administrado de maneira razoável e proporcional (formas de limites materiais) ao eventual comportamento ameaçador do interesse público, sempre observando, pois, o que autoriza a lei (limite formal).

Tais limites também se justificam pela proibição legal do abuso e desvio de poder por parte da Administração Pública, a fim de impedir arbitrariedades contra o indivíduo social.

Insta salientar que até mesmo a Lei $n^{\circ} 9.784 / 1999$, que regula o processo administrativo no âmbito da Administração Pública Federal, em seus artigos $1^{\circ}$ e $2^{\circ}$, faz menção aos princípios da 
razoabilidade, proporcionalidade e legalidade como norteadores do processo administrativo da Administração Pública Federal:

Art. $1^{\circ}$ Esta lei estabelece normas básicas sobre o processo administrativo no âmbito da Administração Pública Federal direta e indireta, visando, em especial, à proteção dos administrados e ao melhor cumprimento dos fins da Administração.

Art. $2^{\circ}$ A Administração Pública obedecerá, dentre outros, aos princípios da legalidade, finalidade, motivação, razoabilidade, proporcionalidade, moralidade, ampla defesa, contraditório, segurança jurídica, interesse público e eficiência. (grifo nosso)

Vale transcrever, aqui, a previsão expressa do parágrafo único do art. 78 do Código

Tributário Nacional:

Parágrafo único. Considera-se regular o exercício do poder de polícia quando desempenhado pelo órgão competente nos limites da lei aplicável, com observância do processo legal e, tratando-se de atividade que a lei tenha como discricionária, sem abuso ou desvio de poder. (grifo nosso)

José dos Santos Carvalho Filho (2007, p. 81) assim dispõe sobre o princípio da proporcionalidade:

O princípio da proporcionalidade deriva, de certo modo, do poder de coerção de que dispõe a Administração ao praticar atos de polícia. Realmente, não se pode conceber que a coerção seja utilizada indevidamente pelos agentes administrativos, o que ocorreria, por exemplo, se usada onde não houvesse necessidade.

Com efeito, é essencial que a medida de polícia adotada pelo agente seja proporcional ao fim perseguido, isto é, quando seja realmente preciso agir daquela forma ou quando não haja outro mecanismo mais ameno para evitar a agressão ao bem-estar geral. 
Utilizar meios extremos ou exagerados a fim de impedir ameaças hipotéticas ao interesse coletivo constitui abuso de autoridade do Poder Público. Assim "tem de existir proporcionalidade entre os males a evitar e os meios a empregar para a sua prevenção" (CAETANO, 1991, p. 1159).

Maria Sylvia Zanella Di Pietro (2007, p 109), que chama o princípio ora em análise de "proporcionalidade dos meios aos fins", ensina que o preceito traduz a ideia de que o poder de polícia não deve ir além do necessário para satisfação do interesse coletivo que visa proteger, já que seu objetivo não é destruir os direitos individuais, mas, ao contrário, assegurar o seu exercício.

No que tange à necessidade de atuação proporcional da autoridade administrativa, em relação à finalidade que se busca, é preciso que esta se comporte com extrema cautela, "nunca se servindo de meios mais enérgicos que os necessários à obtenção do resultado pretendido pela lei, sob pena de vício jurídico que acarretará responsabilidade da Administração” (MELLO, 2006, p. 801).

Observa-se assim, que em decorrência dos atos desproporcionais abusivos, haverá responsabilização do Poder Público, na pessoa de seu agente, sendo considerado o ato administrativo absolutamente nulo. É o que ocorre, por exemplo, em situações em que, com a finalidade de simplesmente dissolver manifestação pacífica, porém de certa forma inconveniente ao interesse coletivo, o agente administrativo utiliza da força física com violência, agredindo manifestantes desarmados; ou na hipótese de, sendo necessária a interdição de restaurante irregular, por não observar normas de higiene e salubridade, a autoridade competente dilapidar o patrimônio do referido estabelecimento.

Quando falamos em razoabilidade no exercício do poder de polícia, trabalha-se com ideia de limitação da atuação do agente público, no sentido de exigir deste uma conduta equivalente ao que qualquer indivíduo comum teria. Deve a administração agir de forma racional, sem fugir do senso comum. 
Neste sentido, leciona Diógenes Gasparini (2005, p. 23-24):

O particular, salvo alguma anomalia, não age de forma desarrazoada. Seu comportamento, diante das mais variadas situações, predispõe-se, sempre, a seguir o sentido comum das pessoas normais. Assim também deve ser o comportamento da Administração Pública quando estiver no exercício de atividade discricionária, devendo atuar racionalmente e afeiçoada ao senso comum das pessoas, tendo em vista a competência recebida para a prática, com discrição, de atos administrativos.

Segundo Celso Antônio Bandeira de Mello (2006, p. 105), o princípio da razoabilidade enuncia que a autoridade administrativa, ao atuar no exercício de discrição, deve "obedecer a critérios aceitáveis do ponto de vista racional, em sintonia com o senso normal de pessoas equilibradas e respeitosa das finalidades que presidiram a outorga da competência exercida”. O princípio se justifica em razão da necessidade de limitar a atuação discricionária da Administração, sendo a sua inobservância identificada por comportamentos bizarros da autoridade administrativa, ou seja, incoerentes ou em desconsideração às circunstâncias que seriam observadas por quem tivesse características normais de prudência. $^{7}$

Enfim, no tocante ao princípio da Legalidade, este impede que o Poder Público, na atividade de polícia, exerça atos contrários ao que a legislação prevê, ou até mesmo use de medidas coercitivas de que a lei não faça menção ou não lhe dê discricionariedade para agir.

No âmbito do exercício das limitações administrativas, deve haver respaldo à lei e observância sempre dos direitos constitucionais (MOTTA, 1999, p. 544.). A Constituição Federal e as legislações em geral devem sempre servir como base para o ato de polícia administrativa. ${ }^{8}$

Na esteira de tal posicionamento, o princípio da legalidade é considerado, na nossa ótica, preceito norteador de todos os outros analisados, em razão de estar, na autorização legal, a base para 
o exercício das limitações administrativas, sem o qual não há que se falar em atuação

desproporcional ou fora da razoabilidade pelo agente público. É obrigação dele, primeiro de tudo, obedecer ao que a lei prevê.

\section{Considerações finais}

Ante todos os argumentos apontados no presente trabalho, tem-se a certeza da enorme importância do estudo das formas de limitação do poder de polícia administrativa, exercido pelo Poder Público.

O poder de polícia, como forma de limitação da propriedade e das liberdades individuais dos administrados, em prol do interesse público, é de extrema relevância para a garantia da ordem e do bem estar social.

Assim, o Direito dá à Administração Pública os mecanismos necessários à restrição do uso da propriedade, da liberdade e dos direitos individuais do cidadão, em benefício da coletividade. Através do poder de polícia, o Estado terá condições de impedir atitudes inconvenientes ou perturbadoras do indivíduo, em relação à coletividade.

No entanto, é fato que o exercício de tal poder estatal, mesmo que objetivando a satisfação do interesse geral, é considerada a maior demonstração da efetiva e direta invasão deste na esfera individual do particular, legitimando, inclusive, o uso da força pelo Estado-Administração.

Trata-se, portanto, de situação que se insere, diretamente, na relação Estado-indivíduo, mais precisamente na questão autoridade-liberdade.

Com efeito, surge a relevância da limitação desta atuação estatal na vida do indivíduo social, atuação esta que visa o controle e a restrição de seus direitos e liberdades, isto é, garantias que, historicamente, sempre foram objeto da luta do particular, ao exigir do Estado uma abstenção de 
prestações de caráter social.

O poder de polícia não é absoluto ou ilimitado, visto que o ato administrativo de polícia, seja ele específico ou de caráter geral, não pode visar, jamais, à abolição de direitos ou liberdades do administrado, ferindo garantias constitucionais e legais conferidas aos mesmos ou causando-lhes prejuízos injustos.

Neste diapasão, a polícia administrativa está sujeita a "barreiras" no que tange sua atuação na esfera privada do indivíduo. Tais limites estão relacionados aos direitos fundamentais (assegurados na Constituição Federal), aos elementos ou pressupostos do ato administrativo e aos princípios da legalidade, proporcionalidade e razoabilidade.

Assim, os direitos individuais fundamentais, garantidos no art. $5^{\circ}$ da Carta Magna, não podem, via de regra, ser suprimidos, mesmo que em prol do interesse geral. No entanto, a ordem social deve sempre ser preservada, sendo necessária a conciliação entre tais direitos fundamentais e o interesse público.

Por outro lado, os atos de polícia estatal também serão limitados através da obrigatoriedade de observância dos pressupostos de validade do ato administrativo. Assim, como todo ato do Poder Público, a atividade de polícia deve ser exercida em obediência à competência, à finalidade, à forma, ao motivo e ao objeto do ato praticado.

Por fim, a polícia administrativa deve ser praticada em observância aos princípios da legalidade, proporcionalidade e legalidade. A fim de impedir arbitrariedades e abusos de poder por parte do Estado, ferindo e restringindo injustamente direitos e liberdades individuais, a Administração Pública deve agir em consonância ao que lei prevê, nunca atuando contra ela, ou em desacordo ao texto legal. Também, não devem seus agentes exercer atos de polícia administrativa que se apresentem como desproporcionais ou sem a razoabilidade, coerência e prudência que se 
exige de todo homem racional e normal, tudo com o fim de impedir arbitrariedades, abusos de poder e intervenções excessivas na esfera jurídica do particular.

\section{Notas}

${ }^{1}$ Segundo o autor, a hipótese se refere "ao complexo de medidas do Estado que delineia a esfera juridicamente tutelada da liberdade e da propriedade dos cidadãos”.

${ }^{2}$ Celso Antônio Bandeira de Mello apresenta o seguinte exemplo: “As limitações ao direito de construir firmadas em favor de um objetivo urbanístico estético, tal a que favorece perspectivas e dimensões que embelezam uma área citadina, ou a que beneficia uma "perspectiva" monumental, visam não só a salvaguardar, mas, até mesmo “construir” um valor estético em benefício da cidade. É claro que também se poderia dizer que estas medidas típicas do poder de polícia evitariam um prejuízo, consistente no enfeamento da cidade, que, à sua falta, se produziria. No fundo, a questão se resolve no modo de encarar o mesmo fato".

${ }^{3}$ Utilizando-se como argumento o atributo da auto-executoriedade, já julgou o Tribunal Regional Federal da $2^{\text {a }}$ Região: PROCESSUAL CIVIL. ART. 557, CAPUT, DO CPC. AGRAVO INTERNO. CONSELHO REGIONAL DE ADMINISTRAÇÃO DO RIO DE JANEIRO. FUNÇÃO FISCALIZATÓRIA. PODER DE POLÍCIA. AUTOEXECUTORIEDADE. INTERVENÇÃO DO PODER JUDICIÁRIO. DESNECESSIDADE. I - Os Conselhos fiscalizatórios detêm poder de polícia, o qual possui como atributo a autoexecutoriedade, consubstanciada na faculdade de decidir e executar diretamente as decisões por meios próprios, bem como de impor as penalidades que entender cabíveis sem que para isso necessitem da intervenção do Poder Judiciário. II - Havendo embaraço à fiscalização, as entidades de classe podem e devem aplicar as sanções legais cabíveis, no exercício do poder de polícia que lhes é conferido por lei. BRASIL. Tribunal Regional Federal da $2^{a}$ Região. Agravo interno na apelação cível. Processo: 1999.51.01.004102-8 UF : RJ. Órgão Julgador: Sétima Turma Esp. Data Decisão: 19/10/2005. Disponível em: 
$<$ http://www2.trf2.gov.br/NXT/gateway.dll?f=templates\&fn=default.htm\&vid=base_jud:v_jur> Acesso em: 03 set. 2007.

${ }^{4}$ A título de exemplificação, o ato coercitivo de polícia administrativa pode ser verificado em diversas situações em que a ordem pública seja ameaçada, como em manifestações violentas, tumultos urbanos ou greves ilegais em que trabalhadores se apoderam da fábrica, recusando a desocupá-la.

${ }^{5}$ Utilizando-se do mesmo fundamento, já julgou a Suprema Corte: "HABEAS CORPUS. PREVENTIVO. AUSÊNCIA DE PROVA DE AMEAÇA IMINENTE DE PRISÃO. OS LIMITES DO PODER DE POLICIA SÃO DEMARCADOS PELO INTERESSE SOCIAL, EM CONCILIAÇÃO COM OS DIREITOS FUNDAMENTAIS DOS INDIVIDUOS, ASSEGURADOS PELA CONSTITUIÇÃO. PRECEDENTE DO STF, DENTRE OUTROS, NO RHC 59.518-SP. RECURSO DESPROVIDO.”

6 "O conceito de forma pode ser considerado, naturalmente, em sentido e extensão diversos. Assim falamos de forma nos referindo às exigências necessárias para existência, validade e eficácia legal dos atos. Entendemos também, por forma, a estrutura do ato, isto é, a maneira como a declaração de vontade é manifestada que necessariamente supõe todo ato administrativo. Fala-se, finalmente, em forma, fazendo referência à esfera jurídica em que o ato nasce ou se produz, em seu virtude, à figura legal que se apresenta."

7 Com base neste mesmo princípio, julgou o Superior Tribunal de Justiça o Recurso Ordinário número 20851/MS: [...]1. "O princípio da razoabilidade é uma norma a ser empregada pelo Poder Judiciário, a fim de permitir uma maior valoração dos atos expedidos pelo Poder Público, analisando-se a compatibilidade com o sistema de valores da Constituição e do ordenamento jurídico, sempre se pautando pela noção de Direito justo, ou justiça" (Fábio Pallaretti 
Calcini, O princípio da razoabilidade: um limite à discricionariedade administrativa. Campinas: Millennium Editora, 2003) [...]

8 Neste sentido, STJ: DIREITO ADMINISTRATIVO. RECURSO ORDINÁRIO EM MANDADO DE SEGURANÇA. PROCON. APLICAÇÃO DE MULTA NO EXERCÍCIO DO PODER DE POLÍCIA. PRINCÍPIO DA LEGALIDADE. AUSÊNCIA DE TIPICIDADE DA INFRAÇÃO. 1. O procedimento administrativo pelo qual se impõe multa, no exercício do Poder de Polícia, em decorrência da infringência a norma de defesa do consumidor deve obediência ao princípio da legalidade. É descabida, assim, a aplicação de sanção administrativa à conduta que não está prevista como infração. 2. Recurso ordinário provido. (BRASIL. Superior Tribunal de Justiça. RMS 19510 / GO. Relator(a) Ministro Teori Albino Zavascki. Órgão Julgador T1 - Primeira Turma. Data do Julgamento 20/06/2006. Disponível em: www.stj.gov.br. Acesso em 12 nov. 2014.)

\section{Referências bibliográficas}

ARAÚJO, Rodrigo Henriques de. Independência funcional como princípio de atuação dos procuradores municipais. In: NERY, Cristiane da Costa; CAMPELLO, Geórgia Teixeira Jezler (Coord.). Direito municipal em debate. Belo Horizonte: Fórum, 2014. v. 2, p. 213-229.

AZAMBUJA, Darcy. Teoria Geral do Estado. 37. ed. São Paulo: Globo, 1997.

BASTOS, Celso Ribeiro. Curso de Direito Administrativo. 2. ed. São Paulo: Saraiva, 1996.

BIELSA, Rafael. Direcho Administrativo. Tomo I. 3. ed. Buenos Aires: J. Lajouane y Cia. Libreros y Editores, 1938.

CAETANO, Marcello. Manual de Direito Administrativo, Vol. II. 10. ed. Coimbra: Almedina Coimbra: 1991. 
CARVALHO FILHO, José dos Santos. Manual de Direito Administrativo. 17. ed. Rio de Janeiro: Lumen Júris, 2007.

CIRNE, apud FREITAS, Juarez. Estudos de Direito Administrativo. 2. ed. São Paulo: Malheiros, 1997.

CUNHA, Leonardo Carneiro da. A Fazenda Pública em juízo. 12 ed. São Paulo: Dialética, 2014.

DI PIETRO, Maria Sylvia Zanella. Direito Administrativo. 19. ed. São Paulo: Atlas, 2006. . Direito Administrativo. 20. ed. São Paulo: Atlas, 2007.

GASOS, Iara Leal. A Omissão Abusiva do Poder de Polícia. Rio de Janeiro: Lumen Juris, 1994.

GASPARINI, Diógenes. Direito Administrativo. 10. ed. ver. e atual. São Paulo: Saraiva, 2005.

GORDILLO, Agustín. Tratado de Derecho Administrativo, 1. tomo: Parte General. 7. ed. Belo Horizonte: Del Rey e Fundación de Derecho Administrativo, 2003.

Tratado de Derecho Administrativo, 2. tomo: La defensa del usuario y del administrado. 5. ed. Belo Horizonte: Del Rey e Fundación de Derecho Administrativo, 2003.

KFOURI FILHO, Abrahão José. Compêndio de Direito Administrativo. 2. ed. São Paulo: Terra Editora, 1998.

MAFRA, Francisco. Administração pública burocrática e gerencial. In: Âmbito Jurídico, Rio Grande, VIII, n. 21, maio 2005. Disponível em: <http://www.ambitojuridico.com.br/site/index.php?n_link=revista_artigos_leitura\&artigo_id=503>. Acesso em maio 
MEDAUAR, Odete. Direito Administrativo Moderno. 9. ed. rev. e atual. São Paulo: Revista dos Tribunais, 2005.

MEIRELLES, Hely Lopes. Direito Administrativo Brasileiro. 29. ed. São Paulo: Malheiros, 2004.

MELLO, Celso Antônio Bandeira de. Curso de Direito Administrativo. 18. ed. São Paulo: Malheiros, 2005.

. Curso de Direito Administrativo. 21. ed. São Paulo: Malheiros, 2006.

MOTTA, Carlos Pinto Coelho. Curso Prático de Direito Administrativo. Belo Horizonte: Del Rey, 1999.

MÜLLER, Friedrich. Quem é o povo? A questão fundamental da democracia. São Paulo: Max Limonad, 1998.

PEDRA, Adriano Sant’Ana. “A importância da Advocacia Pública de Estado para a democracia constitucional". Advocacia pública de estado: estudos comparativos nas democracias euro-americanas./ coordenação de Adriano Sant'Ana Pedra, Julio Pinheiro Faro, Pedro Gallo Vieira. Curitiba: Juruá, 2014.

RIVERO, Jean. Direito Administrativo. Coimbra: Almedina, 1981.

SARMENTO, Daniel (Org). Interesse público versus interesse privado: desconstruindo o princípio da supremacia do interesse público. Rio de Janeiro: Lumen Juris, 2007.

SCHIESARI, Nélson. Direito Administrativo. 4. ed. São Paulo: Saraiva, 1982.

SPITZCOVSKY, Celso. Direito Administrativo. 8. ed. São Paulo: Damásio de Jesus, 2006. 
SUNDFELD, Carlos Ari. Interesse Público em sentido mínimo e em sentido forte: o problema da vigilância epidemiológica frente aos direitos constitucionais. INTERESSE PÚBLICO: Revista Bimestral de Direito Público. Porto Alegre: Notadez, ano 6, $\mathrm{n}^{\circ}$ 28, novembro/dezembro de 2004.

VIEIRA, Pedro Gallo. VIEIRA, Andrea Maria dos Santos Santana. A unidade do interesse público como consectário do estado democrático de direito a importância da Advocacia-Geral da União na legitimação dos interesses dos cidadãos. In: Emerson Gabardo; Giovani da Silva Corralo; Maria Goretti Dal Bosco. (Org.). Direito e Administração Pública II. 1ed. Florianópolis: Fundação José Arthur Boiteux, 2013, v. 1, p. 193-214. 